\begin{tabular}{llllllll}
\hline $\mathrm{A}$ & $\mathrm{R}$ & $\mathrm{T}$ & $\mathrm{Y}$ & $\mathrm{K}$ & $\mathrm{U}$ & $\mathrm{E}$ & $\mathrm{Y}$
\end{tabular}

ANNA PAULINA OREOWSKA

https://orcid.org/0000-0003-3025-6165

Zakład Atlasu Historycznego Instytutu Historii im. Tadeusza Manteuffla Polskiej Akademii Nauk (współpracowniczka)

PATRYCJA SZWEDO-KIEŁCZEWSKA

https://orcid.org/0000-0003-0705-0011

Wydział Nauk o Kulturze i Sztuce Uniwersytetu Warszawskiego

\title{
OXEN TRADE FROM THE FIFTEENTH CENTURY TO THE BEGINNING OF THE SEVENTEENTH CENTURY AND ITS RELATIONS WITH THE ENVIRONMENT AND SPACE - CASE STUDY OF GREATER POLAND ${ }^{1}$
}

Zarys treści: Artykuł koncentruje się na zależnościach zachodzących między środowiskiem naturalnym, przestrzenią miejską i handlem wołami. Na podstawie źródeł pochodzących z terenów Wielkopolski omówiono specyficzne uwarunkowania dotyczące handlu żywym inwentarzem (trasy, tempo przepędu, konieczność wypasu i popoju zwierząt), zwrócono uwagę na pomijane dotąd zagadnienia związane $\mathrm{z}$ koniecznościa dostosowania przestrzeni miejskiej do wymagań handlu wołami na szeroką skalę, który rozkwitał podczas jarmarków odbywających się w poszczególnych ośrodkach miejskich, postulując przy tym konieczność pogłębienia badań w tym zakresie.

The content outline: The paper focuses on the interrelations between the environment, urban space, and oxen trade. On the basis of sources from the region of Greater Poland, it discusses particular conditions of trade in livestock (routes, pace of driving the animals, the need to feed and give water to the oxen). It also points to thus far ignored issues connected with indispensable adaptation of the urban space to the needs of the large-scale oxen trade which flourished during fairs taking place in various towns and emphasises the necessity to carry out further research in this regard.

1 The research for this paper was carried out as part of the grant no. 2016/21/P/ HS3/04034 of the National Science Centre, Poland. This project has received funding from the European Union's Horizon 2020 research and innovation programme under the Marie Skłodowska-Curie grant agreement no. 665778. 
Słowa kluczowe: przestrzeń miejska, jarmarki, handel wołami, środowisko

Keywords: urban space, fairs, oxen trade, environment

\section{Introduction}

In medieval times, the organisation and infrastructure of trade were subject to a variety of factors and conditions, both man-made and geographical. These included the location of roads, bridges, custom houses, taverns, modes of transport, levels of trading fees, or distribution channels. The complexity of this issue is reflected by the great abundance of literature discussing most of the factors mentioned above. However, some aspects still require our attention. One such research problem is the influence of the natural environment and space on long-distance trade. The issue that still requires to be comprehensively studied is the way geographical location impacted the speed and quality of transport. This was particularly important for livestock trade, not only in the process of driving the cattle but also during layovers and stops in towns during fairs. The state of municipal infrastructure and availability of pastures and water translated to the organisation and spatial arrangement of town fairs as well. The issues have already been discussed by researchers, but mainly in very general terms. For this reason, this article seeks to investigate the topic and exhibit new research opportunities and avenues concerning the relations between spatial arrangement of towns and livestock trade, oxen in particular. Still, the principal aim of the article is to suggest some research directions rather than to present a synthetic interpretation of the source material. In our deliberations on the issues related to the importance of the natural environment and space in cattle trade, we have focused on the territory of Greater Poland, but in order to give the discussion a wider context, we have also used sources and examples from other areas.

\section{Greater Poland as a region involved in oxen trade}

The end of the fourteenth century brought political and economic transformations which resulted in long-distance international trade becoming a factor stimulating and intensifying the local markets in Poland. ${ }^{2}$

${ }^{2}$ M. Małowist, Studia z dziejów rzemiosła $w$ okresie kryzysu feudalizmu $w$ Zachodniej Europie w XIV i XV wieku, Warszawa, 1954, passim; id., Wschód a Zachód Europy 
Great overland commercial traffic on the East-West axis flourished. ${ }^{3}$ In this context, the establishment of a new polity - the Polish-Lithuanian Commonwealth - in 1385, and the subsequent inclusion of Lithuania in the community of Roman Catholic countries, was a true turning point. The event coincided with attempts to emerge from the economic crisis which affected the western part of the continent, resulting in including the East in the European economy. ${ }^{4}$ The political and economic changes led to a transformation in the axes of trade routes connecting Polish lands with other European countries. ${ }^{5}$ It is also worth mentioning the correlations between the development of the network of towns, their geographical distribution, and the course of European trade routes. ${ }^{6}$ However, it was in the sixteenth century that international trade saw its true heyday; the price revolution in Western Europe brought increased demand for food and natural resources from Poland. ${ }^{7}$ The principal food products transported on this route in this period (until the second half of the seventeenth century) were grains and oxen. ${ }^{8}$

The fifteenth century was also a period of incredibly intense development of fair networks in north-western Europe. Coming into shape was a web of interconnected, hierarchical markets, from international fairs in Antwerp to humble, local markets; Stuart Jenks named this process the "distribution revolution" without which the later consumer revolution of the eighteenth century would be inconceivable. ${ }^{9}$ A similar

w XIII-XVI. Konfrontacja struktur społeczno-gospodarczych, Warszawa, 1973, passim; H. Samsonowicz, "Polska w gospodarce europejskiej późnego średniowiecza", in: Pamiętnik Powszechnego Zjazdu Historyków Polskich w Lublinie, vol. 1, Warszawa, 1968, pp. 92-93.

${ }^{3}$ See M. Małowist, Wschód a Zachód..., pp. 41-252.

${ }^{4}$ H. Samsonowicz, A. Mączak. "Feudalism and Capitalism. A Balance of Changes in East-Central Europe", in: East-Central Europe in Transition from Fourteenth to the Seventeenth Century, ed. A. Maczak, H. Samsonowicz, P. Burke, Cambridge, 1985, pp. 8-9.

${ }^{5}$ H. Samsonowicz, "Przemiany osi drożnych w Polsce późnego średniowiecza", Przeglad Historyczny, 64, 1973, no. 4, p. 712.

${ }^{6}$ H. Zaremska, "Z dziejów handlu polsko-litewskiego: lokacje w Koronie i na Mazowszu w latach 1386-1501", Przeglad Historyczny, 64, 1973, no. 4, pp. 717-728.

${ }^{7}$ M. Dygo, "Wschód i Zachód: gospodarka Europy w XIV i XV wieku”, in: Ziemie polskie wobec Zachodu. Studia nad rozwojem średniowiecznej Europy, ed. R. Czaja, M. Dygo, S. Gawlas, G. Myśliwski, K. Ożóg, Warszawa, 2006, p. 194.

8 A. Dunin-Wasowiczowa, "Spatial Changes in Poland under the Impact of the Economic of the $16^{\text {th }}$ and $17^{\text {th }}$ Centuries", in: The Early-Modern World-System in Geographical Perspective, ed. H.J. Nitz, Stuttgart, 1993, pp. 172-190.

9 S. Jenks, "The Missing Link: Distribution Revolution the $15^{\text {th }}$ Century", in: Textiles and Medieval Economy: Production, Trade and Consumption of Textiles $8^{\text {th }}$ to $16^{\text {th }}$ Centuries, ed. A.L. Huang, C. Jahnke, Oxford, 2015, p. 230-252. 
phenomenon could be observed in Poland as well. ${ }^{10}$ There was a significant increase in the number of fairs established in many towns of the Polish Crown, even in small centres assigned the third or fourth tax category ${ }^{11}$; the process began already in the fifteenth century and was in full swing in the sixteenth century.

An area particularly robust in economic development and closely involved in the great European trade was Greater Poland. ${ }^{12}$ It bordered Silesia, Pomerania, and Saxony, which were important and economically

${ }^{10}$ On the importance of annual fairs for the transregional East-West trade: G. Myśliwski, "Strefa sudecko-karpacka i Lwów. Miejsce Ślaska, Małopolski i Rusi Czerwonej w gospodarce Europy Zachodniej (połowa XIII-początek XVI wieku)", in: Ziemie polskie wobec Zachodu. Studia nad rozwojem średniowiecznej Europy, ed. R. Czaja, M. Dygo, S. Gawlas, G. Myśliwski, K. Ożóg, Warszawa, 2006, pp. 262-269. Several important works considering the development of fairs in the Kingdom of Poland have been written so far, i.a.: M. Bogucka, "Fairs in Early Modern Poland", in: Jahrmärkte und Stadtentwicklung in Europa = Foires, marchés annuels et développement urbain en Europe, ed. F. Irsigler, M. Pauly, Trier, 2007, pp. 243-251; ead., "Peoples of the Fairs. Fairs. Organizers and Participants in the Early Modern Poland", in: Fiere e mercati nella integrazione delle economie europee. Secc. XIII-XVIII. Prato, 8-12 maggio 2000, ed. S. Cavaciocchi, Firenze, 2001, pp. 921-932; A. Czacharowski, "Jahrmärkte und Messen im mittelalterlichen Polen”, in: Fiere e mercati..., pp. 235-241; R. Czaja, "Gospodarcze znaczenie jarmarków w państwie zakonu krzyżackiego w Prusach", in: Studia nad dziejami miast i mieszczaństwa w średniowieczu, vol. 2, ed. R. Czaja, J. Tandecki, Toruń, 1996, pp. 121-132; id., "Jahrmärkte im Ordensland Preußen im Mittelalter", in: Das Preußenland als Forschungsaufgabe. Eine europäische Region in ihren geschichtlichen Bezügen, ed. B. Jähnig, Lüneburg, 2000, pp. 319-328; B. Grochulska, "Jarmarki w handlu polskim w drugiej połowie XVIII w.", Przeglad Historyczny, 64, 1973, no. 4, pp. 793-820; J. Kurkowski, "Sieć jarmarczna województwa lubelskiego w XVI wieku", Kwartalnik Historii Kultury Materialnej, 34, 1986, no. 2, pp. 37-59; J. Kuś, "Jarmarki jarosławskie i ich wpływ na rozwój miasta w XVI i XVII wieku", Rocznik Historyczno-Archiwalny, 9, 1995, pp. 29-43; P. Paluchowski, "Miejsca i terminy jarmarków na terenie Prus Królewskich i Książęcych w końcu XVI wieku na podstawie wykazów z gdańskich kalendarzy”, Czasy Nowożytne, 24, 2011, pp. 37-59; H. Samsonowicz, "Jarmarki w Polsce na tle sytuacji gospodarczej w Europie w XV - XVI w.", in: Europa - Stowiańszczyzna - Polska, ed. J. Bardach, Poznań, 1970, pp. 523-532; id., "Les foires en Pologne au XV ${ }^{\mathrm{e}}$ et $\mathrm{XVI}^{\mathrm{e}}$ siècles sur la toile de fond de la situation en Europe", in: Der Außenhandel Ostmitteleuropas 1450-1650, ed. I. Bog, Wien, 1971, pp. 246-259; id., "Niektóre cechy charakterystyczne sieci jarmarcznej w Polsce późnego średniowiecza", in: Studia nad dziejami miast i mieszczaństwa w średniowieczu, vol. 1, ed. M. Bogucka, A. Czacharowski, Toruń, 1996, pp. 37-59; A. Wyrobisz, "Uwagi o kalendarzu jarmarków w miastach Korony w XVI wieku", in: Studia nad dziejami miast..., pp. 27-32. Nevertheless, this topic still requires further research.

${ }^{11}$ Dzieje miast $i$ mieszczaństwa $w$ Polsce przedrozbiorowej, ed. H. Samsonowicz, M. Bogucka, Wrocław, 1986, pp. 105-123; M. Słoń, "Miasta prywatne w sieci miejskiej Wielkopolski XV-XVI wieku", RDSG, 77, 2016, pp. 93-123.

${ }^{12}$ The area of Greater Poland proper, that is, Poznańskie and Kaliskie provinces. 
well-developed regions. It served as a crossroads of routes from the Grand Duchy of Lithuania to Western Europe and from the south to the Baltic region, with its primary port in Gdańsk. This advantageous location determined the status of some Greater Poland towns in wholesale trade..$^{13}$ Analyses conducted in our project have so far indicated that the region's localities boasted 255 fair privileges, and 383 new fairs were established in this area from the second half of the fourteenth century to the second half of the seventeenth century. It is worth taking a closer look at the substantial increase in the number of established fairs in the researched period revealed in our studies. While there were only 38 established fairs in the fifteenth century, the number grew by 230 in the sixteenth century and 108 in the first half of the seventeenth century. This increase is not proportional to the number of preserved fair privileges, since there were only 30 of those in the fifteenth century, 151 in the sixteenth century, and 66 in the seventeenth century. The significance of fairs for towns is evidenced not only by their growing number but also by the fact that clauses establishing fairs were included in the text of the town location charters. Even if such clauses were initially just an exception, they later became a standard part of such charters. The fair had started to define the town itself.

It was often difficult to determine whether the clauses concerning fairs were tantamount to their actual existence or simply a legal provision with no connection to reality. Whether a fair was organised and proved successful depended on a range of factors connected with the distribution of goods, e.g. advantageous location on trade routes, distance from other trade centres, and overall infrastructural and spatial potential of a given town. Therefore, apart from the potentially unreliable sources in the form of royal privileges establishing the fair itself, the main materials we should consult in studying fairs are documents regulating trade relations, royal inspections, inventories, and tax registers, as well as records produced by municipal chancelleries, i.e. town council registers, resolutions (German: Willkür), and financial records. One rare source is a sixteenth-century register of fairs specialising in oxen trade. ${ }^{14}$

Livestock, especially oxen - the second most important merchandise in the Polish export in the early modern period - was distinctive when

${ }^{13}$ Some remarks on the role of Greater Poland in European wholesale trade of oxen: A.-M. Girllmaier, Fleisch für die Stadt. Ochsenimporte nach Augsburg und Nürnberg im 15. und 16. Jahrhundert, Augsburg, 2018, p. 46-51.

${ }_{14}$ A.P. Orłowska, B. Nowożycki, G. Pac, "Handel wołami na terenie Wielkopolski i Ślaska w świetle szesnastowiecznego spisu jarmarków i komór celnych", Studia Geohistorica, 4, 2016, pp. 153-161. 
it came to trade-induced exploitation of available resources and transformation of the natural landscape. ${ }^{15}$ In terms of agriculture specialisation, Greater Poland was not a homogeneous region. Its eastern part focused on grain production, the south-western part combined cereals cultivation with elements of horned cattle breeding, while in the north sheep were bred. ${ }^{16}$ Even though the local animal husbandry sector was far from predominant, oxen trade was quite common. The endeavour involved the import of steppe cattle, mainly from the area of current Ukraine, keeping it over winter, fattening, and subsequently selling it in Silesia or the Reich. ${ }^{17}$ Issues regarding breeding, space management, and ensuring appropriate conditions for animals in the researched period pertain not only to areas directly linked to agriculture, namely the countryside and small towns. As the research has shown so far, this activity largely involved the burghers of Kraków or Torun, thus influencing the landscape of those urban centres. ${ }^{18}$ In Poznan, herds of cattle were grazed on the outskirts of the town by local cart drivers. This is evidenced, for example, by source materials produced after the fire which started in Chwaliszewo (in the vicinity of Poznań, Fig. 4) in 1569 and spread to the left side of the Warta River. The sources report that large herds of cattle and horses fell victim to the blaze. ${ }^{19}$

${ }_{15}$ R. Rybarski, Handel i polityka handlowa Polski $w$ XVI stuleciu, vol. $1,2^{\text {nd }}$ ed., Warszawa, 1958, pp. 247-248 ( $1^{\text {st }}$ ed: Poznań 1928-1930); A. Mączak, "Rinderhandel und Rinderhaltung im nordwesteuropäischen Künstengebiet vom 15. bis zum 19. Jahrhunder', Heinz Wiese, Johan Bölts, Stuttgart 1966: [recenzja]”, Przeglad Historyczny, 60, 1969, no. 4, pp. 731-735.

16 J. Topolski, "Przyczyny powstania i rozwój folwarku pańszczyźnianego", in: Dzieje Wielkopolski do roku 1793, ed. J. Topolski, vol. 1, Warszawa, 1963, p. 457.

17 J. Baszanowski, Z dziejów handlu polskiego $w$ XVI-XVIII $w$. Handel wołami, $2^{\text {nd }}$ ed., Szczęsne, 2017, pp. 65-130 (1 ${ }^{\text {st }}$ ed.: Gdańsk, 1977).

18 J. Wyrozumski, "Hodowla w średniowiecznym Krakowie", in: Czas, przestrzeń, praca $w$ dawnych miastach: studia ofiarowane Henrykowi Samsonowiczowi w sześćdziesiata rocznice urodzin, ed. A. Wyrobisz, M. Tymowski, Warszawa, 1991, pp. 431-435; P.M. Modrzyński, "Prawne aspekty hodowli zwierząt w średniowiecznych miastach ziemi chełmińskiej i terenów przygranicznych", Rocznik Toruński, 42, 2015, pp. 203-220. See also: S. Fornella, "Rola hodowli, rzeźnictwa i handlu mięsem w życiu gospodarczym Świecia nad Wisła”, Studenckie Teki Historyczne, 1, 2002, pp. 9-13.

${ }_{19}$ M. Drozdowski, “Życie gospodarcze miasta”, in: Dzieje Poznania, ed. J. Topolski, Warszawa-Poznań, 1988, p. 474. 


\section{Oxen trade - specific requirements for infrastructure and environmental conditions}

Oxen breeding and trade in the Late Middle Ages and the early modern period is one of the issues in the economic history of Poland which still require comprehensive studies. The issue has been partly tackled by Roman Rybarski, ${ }^{20}$ Marian Wolański, ${ }^{21}$ Maurycy Horn, ${ }^{22}$ and Ekkehard Westermann, ${ }^{23}$ and recently by Maurycy Zajęcki. ${ }^{24}$ Still, the only work which approaches this topic comprehensively as a monograph is a work by Jan Baszanowski. It was published 40 years ago and, while it presents many worthwhile findings, it does not exhaust the issue. ${ }^{25}$ Moreover, the author made it clear that he considered it a starting point for further research, not a definitive conclusion to his studies. The solid framework which he proposed encompassed the discussion of cattle types, the customs system, geographical zoning of oxen trade, its participants and their methods, as well as the economics of trade. According to his findings, Greater Poland and Silesia were the last places where the local merchants could participate in long-distance oxen trade. Having been driven through the regions, the animals would leave the boundaries of Poland, which rendered those territories particularly significant for the assessment of the scale of international cattle trade. The importance of those areas has been corroborated by a recently published instruction for the customs officers who controlled the oxen trade. ${ }^{26}$

According to Rybarski's estimations, the biggest number of oxen were driven to Poznań - as many as 16,658 animals in 1531-1537. ${ }^{27}$ Topolski believes, however, that most of the cattle passing through Poznan's customs house were oxen put on sale at Gniezno fairs. ${ }^{28}$ From there,

${ }^{20}$ R. Rybarski, op. cit., vol. 1-2.

${ }^{21}$ M. Wolański, Zwiazki handlowe Ślaska z Rzeczapospolita w XVII wieku, Wrocław 1961.

${ }^{22}$ M. Horn, "Handel wołami na Rusi Czerwonej w pierwszej połowie XVII wieku", RDSG, 24, 1962, pp. 73-88.

${ }^{23}$ E. Westermann, "Die Bedeutung des Thüringer Saigerhandels für den mitteleuropäischen Handel an der Wende vom 15. zum 16. Jahrhundert”, Jahrbuch für die Geschichte Mittel- und Ostdeutschlands, 21, 1972, pp. 67-92.

${ }^{24}$ M. Zajęcki, "Przepisy dotyczące chowu zwierząt w większych miastach Polski przedrozbiorowej”, Studia z Dziejów Państwa i Prawa Polskiego, 10, 2007, pp. 105-125.

${ }_{25}$ J. Baszanowski, op. cit.

26 A.P. Orłowska, B. Nowożycki, G. Pac, op. cit., pp. 158-161.

${ }^{27}$ R. Rybarski, op. cit., vol. 2, pp. 46-47.

${ }^{28}$ J. Topolski, "Rola Gniezna w handlu europejskim od XV do XVII wieku", Studia i Materiały z dziejów Wielkopolski i Pomorza, 14, 1962, pp. 5-78. 
they were taken abroad by individual merchants or companies. A document from 1532, for example, states that 250 heads of cattle were driven from Gniezno by Błażej Gawron, a burgher from Poznań and a member of a company dealing with such trade. ${ }^{29}$ The register of the customs house in Sandomierz from 1586 lists numerous Greater Poland burghers who drove oxen herds from fairs in the East. ${ }^{30}$ It mentions i.a. inhabitants of Kalisz, Poznań, Koło, or Lwówek, who in July and August drove 4,689 oxen in total. The biggest herd comprised 1,142 animals and was driven by citizen of Poznan Erastin Hanspacher ${ }^{31}$; a person by the name of Grabarz from Lwówek reported 493 animals, ${ }^{32}$ and 352 belonged to Jakub, a Jew from Kalisz. ${ }^{33}$ Jews from Kalisz were granted a special privilege by Casimir IV Jagiellon (reign in Poland: 1447-1492) in 1453. It allowed them to slaughter animals and sell the meat in the entire territory of the Kingdom of Poland, as well as to participate in all markets and fairs. ${ }^{34}$ Nevertheless, more comprehensive studies on the scale and specialisation of trade in this region encounter serious obstacles connected with an insufficient source base - a great number of customs house registers was irrevocably lost as a result of WWII. ${ }^{35}$ Additionally, not all the people engaged in oxen trade paid tolls. Entries in the books of the Crown Register (Polish: Metryka Koronna) list many nobles and royal dignitaries originating from Greater Poland who were given the right to freely drive oxen abroad. ${ }^{36}$ Baszanowski tried to calculate the total number of oxen taken abroad using the information about tolls collected by Rybarski and additional documents; he estimated the total number of exported oxen at approximately 40,000 animals per year in the first half of sixteenth century and 60,000 per year in the second half of sixteenth century.

Oxen trade was a venture of great economic importance and, due to the high income it yielded to the royal treasury, it left its traces in the books kept by the Royal Chancellery. Let us take as an example the

${ }^{29}$ State Archives in Poznań [hereinafter: SAP], Akta miasta Poznania, call no. D 125.

${ }^{30}$ Ksiegi celne Korony $z$ drugiej połowy XVI wieku, ed. S. Kazusek, Kielce, 2017, pp. 195-203.

${ }^{31}$ Ibid., p. 201.

${ }^{32}$ Ibid., p. 200.

${ }^{33}$ Ibid., p. 201.

${ }^{34}$ Lustracja województw wielkopolskich i kujawskich 1616-1620 [hereinafter: LWWK 1616-1620], ed. Z. Górski, R. Kabaciński, J. Pakulski, vol. 1, Wrocław 1994, p. 72.

35 J. Karwasińska, "Archiwa Skarbowe dawnej Rzeczpospolitej”, in: Straty archiwów $i$ bibliotek warszawskich $w$ zakresie rękopiśmiennych źródet historycznych, vol. 1, Warszawa, 1957, pp. 70-125.

36 J. Baszanowski, op. cit., p. 42. 
privilege from 1521 issued by Sigismund I the Old (1507-1548) in which the monarch ratified previous trade entitlements of Poznan merchants pertaining to customs dispensation. The document clearly emphasises that the dispensation is not in force "theloneo tamen novo a bobus, cera et cutibus pridem ob necessitatem reipublicae laudato et constituto," ${ }_{37}$ which was also reiterated in the privilege issued by the king in $1536 .{ }^{38}$ The "new" duty on oxen driven abroad, established temporarily in 1507 (lat. temporaliter statuimus), ${ }^{39}$ in fact remained in force as long as until 1717. ${ }^{40}$ In 1597, Sigismund III Vasa (1587-1632) ratified the customs dispensation for Poznan merchants and extended it to the whole country, excluding the export duty on oxen, leather, and wax. ${ }^{41}$

Likewise, the needs of oxen trade were given particular attention in other documents enacted by the rulers for Greater Poland. In 1493, John I Albert (1492-1501) forbade the general starost to arbitrarily collect duties from Poznań merchants driving cattle to Saxony and warned against placing any obstacles in their way. ${ }^{42}$ In 1519 , Sigismund I the Old issued a law which allowed Poznań merchants and butchers to drive their herds on the trade route from Łęczyca through Poznan and farther through Międzyrzecz to Brandenburg. ${ }^{43}$ In the sixteenth and the seventeenth century, there were two main routes running through Greater Poland: the Sandomierz route and the Lublin route. The route through Sandomierz led to Poznan and then to the Margraviate of Brandenburg, crossing i.a. Łęczyca, Grabów, Koło, Słupsk, Września, Nakło, Bytyń, Pniewy, Pczew, and Międzyrzecz; from there, it branched off and reached Western Pomerania via Skwierzyna. ${ }^{44}$ Another fork ran from Inowłódz to Gdańsk via Brześć Kujawski, Inowrocław, and Nakło ${ }^{45}$ (Fig. 1).

${ }^{37}$ Przywileje miasta Poznania, ed. W. Maisel, Poznań 1994, issue 101.

38 SAP, Akta miasta Poznań, call no. D 113.

${ }^{39}$ Corpus iuris polonici. Sect. 1, Privilegia, statuta, constitutiones, edicta, decreta, mandata regnum Poloniae spectantia comprehendis, vol. 3, Annos 1506-1522 continens typis mandavit adnotationibus instruxit Osvaldus Balzer, published by F. Zigel, Petersburg, 1908, p. 38.

40 J. Baszanowski, op. cit., p. 36.

${ }^{41}$ SAP, Akta miasta Poznania, call no. D 271.

42 SAP, Akta miasta Poznania, call no. D 105.

43 SAP, Akta miasta Poznania, call no. D 205.

${ }^{44}$ L. Koczy, Handel Poznania do połowy XVI w., Poznań, 1930, pp. 198, 202-204.; M. Wolański, op. cit., pp. 53-54; J. Baszanowski, op. cit., pp. 106-117.

${ }^{45}$ General discussion of roads in Greater Poland: S. Weymann, "Ze studiów nad zagadnieniem dróg w Wielkopolsce od X do XVIII wieku", Przeglad Zachodni, 9, 1953, no. 2, pp. 194-253; T. Związek, "Drogi", in: Atlas historyczny Polski. Wielkopolska $w$ drugiej połowie XVI wieku, ed. H. Rutkowski, M. Słoń, pt. 2: Komentarz, indeksy, Warszawa, 2017, pp. 268-291. 
The great number of herds driven through the region required appropriate infrastructure. Henryk Bartoszewicz, who described the trade roads of the Chełmno area, correctly pointed out that the choice of route was determined not only by general conditions and traffic on the roads but also by the basic needs of the animals, such as access to water and feed. As the researcher noted, mass cattle driving necessitated broader roads, preferably without bridges, dams or other expensive crossings; he also indicated the destructive effect herds had on the road infrastructure. ${ }^{46}$ For these reasons, agricultural cultivation in areas abutting trade routes was prohibited. ${ }^{47}$

Mentions of above problems feature prominently throughout royal documents issued for Poznań. In 1533, Sigismund I the Old received a complaint against the inhabitants of the areas surrounding Łęczyca and Koło, who were allegedly narrowing roads and limiting access to water during the stops in cattle driving; such actions were subsequently prohibited by the monarch. ${ }^{48}$ In 1535 , the king ordered the officials of royal towns and villages - vogts (Lat. advocatus, Pol. wójt) and schultheisses (Lat. scultetus, Pol. sottys) - to ensure safety on the roads, especially for cattle merchants. ${ }^{49}$ As it transpires from an earlier privilege, roads on the borders of Międzyrzecz were particularly dangerous due to widespread robberies and raids..$^{50}$ In 1539 , a complaint was made by merchants forced to pass through the village Mostki and pay unexpected tolls because of limited access to the royal road and heavy traffic on the road in the forest. As a result, the king ordered castellan of Biechowo Mikołaj Rusocki, who was responsible for this disturbance, to remove all the obstacles immediately. ${ }^{51}$ Similarly, in 1546, the monarch ordered the general starost of Greater Poland, Andrzej Górka, to remove all hindrances to oxen merchants and ensure that the width of the road was compliant with regulations allowing it to be used for driving cattle herds. ${ }^{52}$ Sigismund II Augustus (1548-1572) later reissued the edict several times after subsequent complaints from merchants. In 1569, road inspectors received written instruction ordering

${ }^{46}$ H. Bartoszewicz, "Drogi handlowe ziemi chełmińskiej", Miscellanea Historico-Archivistica, 6, 1996, p. 54.

47 J. Baszanowski, op. cit., p. 202.

48 SAP, Akta miasta Poznania, call no. D 216.

49 SAP, Akta miasta Poznania, call no. D 219.

50 SAP, Akta miasta Poznania, call no. D 217.

${ }^{51}$ J. Leitgeber, $Z$ dziejów handlu i kupiectwa poznańskiego za dawnej Rzeczypospolitej Polskiej, Poznań 1929, p. 148; SAP, Akta miasta Poznania, call no. D 223.

${ }^{52}$ SAP, Akta miasta Poznania, call no. D 230. 
them to demarcate public routes as 10 ells wide, given their utilisation for driving cattle, among others..$^{53}$

The poor condition of roads used for the transportation of oxen is a separate problem. It is well illustrated by excerpts from documents issued in 1546 and 1553 in which the rulers reminded the administrator of Greater Poland of his duty to maintain the road from Poznań to Pniewy in view of its poor state. ${ }^{54}$ Similarly, in 1570 in Kobylin, Sigismund II Augustus imposed charges on carts and driven animals. The collected funds were allocated to building and repairing bridges and embankments because, as it was noted in the document, the roads from Silesia were swampy and difficult to travel. ${ }^{55}$ The deterioration of roads from Krzywiń to Głogów due to continuous flooding, as well as the need to build a dam, are also mentioned in a document issued by Stephen Báthory (1533-1586) for Krzywin on 22 February $1585 .{ }^{56}$

\section{Oxen trade - the urban space and natural conditions}

Oxen trade was generally conducted during fairs in towns situated on the major routes used for cattle driving. The rhythm of fairs had to eventuate from the pace of oxen transportation. Unfortunately, the sources regarding this matter for the territory of Poland are scanty; our estimations, therefore, will be based on notes of German merchants who drove oxen to Cologne in $1604 .^{57}$ The entire route was $320 \mathrm{~km}$ long and took 12 days to complete, so we can calculate that on average oxen walked ca. $26.6 \mathrm{~km}$ per day. The speed varied on respective stages of the route, as shown in Table 1 . The pace also varied depending on the quality of the road, as in some regions it was much poorer. In 1615, an oxen herd led from Płazów to Wielun, which are approximately $360 \mathrm{~km}$ apart, needed 25 days to cover the distance, travelling $14.4 \mathrm{~km}$ per day on average. ${ }^{58}$ In 1569 , it took an oxen herd 25 days to cover the

${ }_{53}$ VL, vol. 2, Petersburg, 1859, pp. 97-98.

${ }^{54}$ SAP, Akta miasta Poznania, call no. D 245.

55 SAP, Akta miasta Kobylin, call no. I/7.

56 SAP, Akta miasta Krzywiń, call no. I/14.

${ }^{57}$ H. Wiese, J. Bölts, Rinderhandel und Rinderhaltung im nordwesteuropäischen Küstengebiet vom 15. bis zum 19. Jahrhundert, Oldenburg, 1966, pp. 113-115. Baszanowski also analysed this document, however, he erroneously estimated the length of route at $272 \mathrm{~km}$.

58 J. Baszanowski, op. cit., p. 225. 
Table 1. The transport of oxen between Oldenburg and Cologne

\begin{tabular}{|c|c|c|c|c|}
\hline $\begin{array}{c}\text { Name in } \\
\text { primary source }\end{array}$ & Modern name & Date & $\begin{array}{l}\text { Distance from } \\
\text { previous } \\
\text { location [km] }\end{array}$ & Remarks \\
\hline Oldenburg & Oldenburg & 22 Sept. morning & - & \\
\hline Emstede & Emstek & 22 Sept. noon & 38 & \\
\hline Dinckla & Dinklage & 22 Sept. evening & 21 & \\
\hline Vorde & Vörden & 23 Sept. night & 21 & \\
\hline Osenbrugge & Osnabrück & 24 Sept. night & 28 & \\
\hline Glan & Glane & 25 Sept. noon & 16 & \\
\hline Urstelheuschen & $?$ & 25 Sept. night & $?$ & \\
\hline Warendorf & Warendorf & 26 Sept. noon & 25 & From Glane \\
\hline Tonninsheusche & Tönnishäuschen & 26 Sept. night & 16 & \\
\hline Alen & Ahlen & 27 Sept. noon & 7 & \\
\hline Hamm & Hamm & 27 Sept. night & 13 & \\
\hline Kahmen & Kamen & 28 Sept. noon & 17 & \\
\hline Schwerts & Schwerte & 28 Sept. night & 23 & \\
\hline Werningkhausen & Werninghausen & 29 Sept. noon & 21 & \\
\hline Pflogkmaul & $?$ & 30 Sept. noon & $?$ & \\
\hline Beyenburgk & Beyenburg & 30 Sept. night & 23 & $\begin{array}{l}\text { From } \\
\text { Werninghausen }\end{array}$ \\
\hline Mellenkaten & $?$ & 31 Sept. noon & $?$ & \\
\hline Wormbskirchen & Wermelskirchen & 1 Oct. noon & 32 & $\begin{array}{l}\text { From } \\
\text { Beyenburg }\end{array}$ \\
\hline Neyenhaus & $\begin{array}{l}\text { Neuenhaus } \\
\text { (Thier) }\end{array}$ & 1 Oct. night & 17 & \\
\hline Bochem & Buchheim & 2 Oct. & 27 & \\
\hline & & Total: & 326 & \\
\hline
\end{tabular}

$500 \mathrm{~km}$ route from Zamość to Nakło. ${ }^{59}$ Towns in which the cattle were sold had to provide adequate facilities for herds in the form of "natural" infrastructure, such as pastures, grasslands, access to a river, ponds or other water bodies. The significance of such infrastructure in towns is evidenced by the fact that in Nowe Miasto, Korczyn, and Sandomierz, a special charge, so-called "paśne" ("grazing tax"), had to be paid to the royal treasury by merchants wishing to graze cattle in the areas surrounding the town. ${ }^{60}$ In the seventeenth century, paśne was also collected

\footnotetext{
${ }^{59}$ Ibid.

${ }^{60}$ F. Kiryk, Urbanizacja Małopolski: województwo sandomierskie, Kielce, 1994, p. 123.
} 
in Kuyavia. The municipal cowherd of Przemyśl received additional payment during annual fairs. ${ }^{61}$ In 1600, castellan of Gostyń and starost of Brześć Kujawski Michał Sokołowski ceded 12 Polish zlotys from charges collected for cattle feeding to the town of Brześć Kujawski. ${ }^{62}$ The right to graze cattle free of charge in neighbouring starost-owned forests and lands was also granted to the local Dominican Order in the times of Stephen Báthory ${ }^{63}$ As established by Baszanowski, the levies were collected in private towns as well, even though since the sixteenth century they were in principle included in the toll. Some other charges were also in force: "brzegowe" ("riverbank tax") or "dabrowne" ("oakwood tax"), a payment for grazing animals in neighbouring forests. ${ }^{64}$ During the fairs, the farmers living close to the town often leased their pastures to the arriving traders. ${ }^{65}$

Another challenge was adjusting duty collection to the new trade routes. According to the guidelines included in the aforementioned register of Greater Poland and Silesia fairs from the sixteenth century, several routes were used for driving cattle abroad: Gostyń-Góra Śląska, Koźmin-Głogów, Jarocin-Wińsko, Kobylin-Góra Śląsk, Nowe Miasto-Rudno (Fig. 2), as well as the main routes: Jarosław-Leipzig and Sokal-Zerbst. The document lists the most important places for trade in oxen and horses, the presence in which guaranteed the highest profit: Poznań, Gniezno, Kobylin, Koźmin, Gostyń, and Jarocin. ${ }^{66}$ Under the law enacted in 1524, oxen fairs were established in border towns with the aim of accumulating foreign capital; among them, Śrem was particularly significant. ${ }^{67}$ In a parliamentary resolution from 1565 , the following centres were added to the list of localities competing with Silesian and German towns: Czarnków, Kalisz, Kobylin, Koźmin, Międzyrzecz, Poniec, Wschowa, and Zbąszyń. ${ }^{68}$

If those towns were indeed to participate in livestock trade, they needed to possess adequate facilities allowing them to organise this

${ }^{61}$ Najstarsze rachunki przemyskie, ed. A. Łosowska, M. Schmidt, Przemyśl, 2019, pp. 58, 94.

${ }_{62}$ Metryka Koronna Królestwa Polskiego [hereinafter: MK] 145, ff. 154-155.

${ }^{63}$ MK 132, ff. 201-202.

${ }^{64}$ K. Arłamowski, "Klucz medycki starostwa przemyskiego w XVI w.", in: Studia $z$ historii społecznej $i$ gospodarczej poświęcone prof. dr. Franciszkowi Bujakowi, Lwów, 1931, p. 161.

65 J. Baszanowski, op. cit., p. 216.

${ }_{66}$ A.P. Orłowska, B. Nowożycki, G. Pac, op. cit.

67 VL, vol. 1, p. 213; MK 36, f. 853.

${ }^{68} \mathrm{VL}$, vol. 2, p. 48. 
venture efficiently. This is confirmed by the aforementioned sources. In the document issued in 1524 by Sigismund I the Old, we read that fairs were established in conveniently located places with appropriate infrastructure: good roads and an abundance of feed, enough for the cattle belonging to both the royal subjects and foreign merchants. ${ }^{69}$ Another great challenge was the organisation of cattle trade within the town area. In order to display such merchandise, it was necessary to ensure not only ample space but also constant access to feed and water; at the same time, trading in cattle considerably soiled the towns and disturbed their normal operation. Thus, such commercial undertakings at times required finding additional space as well as transforming the natural landscape in order to adapt it to the needs of trade.

Nevertheless, even without the additional impediments, space inside the town walls was limited and not functional enough to rise to the challenges posed by fairs. Let us take, for example, Gniezno, in which insufficient space combined with high popularity of the local fairs led to vehement conflicts. This state of affairs is evidenced by a document issued by Fryderyk Jagiellończyk in 1499, by the force of which the Archbishop of Gniezno forbade carts and horses carrying merchandise to stop on the cathedral square and to use places of worship as lodgings. ${ }^{70}$ Another example illustrating the needs of merchants and pilgrims arriving at fairs in great numbers comes from Częstochowa, where in 1462 Casimir IV Jagiellon allowed for food and feed for animals to be sold in the neighbourhood of the nearby monastery. According to the monarch, the travel to Częstochowa itself could prove too troublesome in this regard, so all the required resources should be readily available upon arrival at the site. ${ }^{71}$ At times, the access to the official market place was limited. In 1537, Sigismund I the Old allowed burghers and merchants from Poznan to sell goods outside towns in which they could not access the market place. The privilege was issued following their complaints concerning difficulties in selling merchandise during markets and fairs in several localities. ${ }^{72}$

${ }^{69}$ VL, vol. 1, p. 214: "quo locorum et viarum compendio et pascuorum copiae, quae circa duo praedicta oppida, major quam alibi suppeditari fertur possint facilius, tam subditi nostri ad pellendos illuc boves, quam etiam ipsi homines externi ad eos, in eisdem locis emendos, ac inde commodius expellendos adhortari."

${ }^{70}$ After: I. Skierska, Sabbatha sanctifices. Dzień święty w średniowiecznej Polsce, Warszawa, 2008, p. 338.

${ }^{71}$ Zbiór dokumentów OO. Paulinów w Polsce, ed. J. Fijałek, vol. 1, Kraków, 1938, issue 515, p. 303-304.

${ }^{72}$ SAP, Akta miasta Poznania, call no. D 221. 
Taking all those observations into account, we should consider the following questions: how was the problem of providing space needed for cattle trade during fairs and markets solved in towns? Was a specific place within a given town allotted for livestock trade and if so, when? Was it selected permanently or only for the duration of a fair? Was there a correlation between its location and access to vital natural resources?

Let us start with the remark that cattle trade, similarly to other kinds of trade, was generally supposed to be conducted at the town market square or an appointed place in its direct surroundings. This principle, even if it resulted in polluting the town, allowed all butchers equal access to livestock and a possibility to check its state of health. Even if the cattle had been bought outside the marketplace, the butcher was obliged to drive them to the market anyway. This rule appears in the Butcher Guilds' statutes repeatedly. ${ }^{73}$

Nevertheless, such a provision could not be observed when the number of traded animals increased sharply, and so it was often suspended during fairs, allowing for the sale of livestock at any location. ${ }^{74}$

A similar problem was faced by the towns which were centres of cattle trade and which with time came to establish additional market places outside the town limits. This happened quite early in Gniezno, renowned for its famous horse and cattle fairs. Its commercial infrastructure on the market square was largely modernised and expanded during the sixteenth century. ${ }^{75}$ As early as 1555 , a document issued by Sigismund II Augustus exempting the estate of Górka brothers from charges mentioned "forum equorum" - a market place abutting their lands, located outside the town walls, near a lake, just by the road to Września and Pyzdry ${ }^{76}$ (Fig. 3, pos. C). According to a document issued by the Butchers' Guild in 1418, the square situated by the water body used for grazing livestock was owned by Poznan butchers specialising in cattle trade at Silesian and Prussian fairs ${ }^{77}$ (Fig. 4). Two cattle pens were located in Piaski; in the sixteenth century, there were probably

${ }^{73}$ G. Adler, "Das großpolnische Fleischergewerk vor 300 Jahren", in: Zeitschrift der Historischen Gesellschaft für die Provinz Posen, 9, 1894, pp. 209-372, for butchers of Poznań: p. 316; of Wschowa: p. 355, issue 10; of Kalisz: p. 313, issue 20.

${ }^{74}$ Ibid., p. 313, issue 19.

${ }^{75}$ Dzieje Gniezna, ed. Jerzy Topolski, Warszawa, 1965, p. 267.

${ }^{76}$ MK 87, ff. 53v-54v; Sigismundi Augusti regis tempora complectens (1548-1572). Vol. 1, Acta cancellariorum 1548-1572, contexuit indicesque adiecit T. Wierzbowski, Varsoviae, 1919, issue 7224.

77 Kodeks Dyplomatyczny Wielkopolski, ed. F. Piekosiński, Poznań, 1908, vol. 5, issue 839; SAP, Cechy miasta Poznania, Cech rzeźników, issue 383. 
also two slaughterhouses there. ${ }^{78}$ The town thus formed a sui generis production line together with the neighbouring Garbary, where hides, horns, and hooves were further processed in the direct vicinity of the river. Nevertheless, we should point out that the statute from 1507 still obliged butchers to take cattle to the market square; therefore, trade was not conducted on the outskirts of the town, or at least not officially. Wholesale transactions were carried out in the town, while the herds were left in the villages outside Poznań. However, a document issued by Casimir IV Jagiellon in 1492 demonstrates that burghers from Skwierzyna were also allowed to use designated lakes, grasslands, pastures, and forests to feed livestock. ${ }^{79}$

Towns which were less involved in livestock trade developed markets outside the town walls much later. For instance, Kalisz already boasted a "Cattle Street" (Pol. ulica Bydlęca) in medieval times. ${ }^{80}$ (Fig. 5) Nevertheless, proposals to establish a separate, permanent market for livestock trade only appeared at the end of the eighteenth century, during the activity of the Commission of Good Order. ${ }^{81}$ Sources from the eighteenth century also mention a livestock market operating beyond the walls and fortifications of Poznan, located at the foot of the castle between the embankments and shooting range. ${ }^{82}$ However, this new, larger space eventually also proved insufficient, as source materials include evidence of attempts to limit the competition among the merchants. According to the decree by the Commission of Good Order issued in 1780, the fairs were classified according to the provenance of goods sold: those specialising in cattle, horses, pigs, and other Polish products (Dominica Oculi, on St. Lucia's Day) and those focusing on the sale of foreign goods (before the Feast of Saint Peter and Paul and Feast of St. Michael the Archangel). Each was to last for two weeks.

In the case of high intensity of trade relative to available space, towns could decide to separate oxen trade from other merchandise. Such a solution was employed in various ways and with varying results. One possibility was to give separate time slots to various sectors of trade and select different dates for cattle trade and for other goods, as described

${ }^{78}$ P. Dembiński, "Poznański zespół osadniczy", in: Atlas historyczny Polski, pp. 292-313.

${ }^{79}$ LWWK 1616-1620, p. 13; AGAD, Archiwum Publiczne Potockich, call no. 304, ff. $45-46 v$.

${ }^{80}$ U. Sowina, T. Związek, T. Panecki, "Kalisz w połowie XVI wieku”, in: Atlas historyczny Polski, pp. 313-332.

81 A.A. Chodyński, Dawne ustawy Kalisza, Warszawa, 1875, p. 71, issue 6.

${ }^{82}$ SAP, Akta miasta Poznania, call no. I/1908, pp. 143-144. 
above. This method was also pursued by Gniezno, whose St. Adalbert's Fairs were dominated by cattle trade. The animals were driven from Russia and spent the winter in Lesser Poland, then reached Greater Poland during springtime. Lack of sufficient space provoked many tensions. Hence, the authorities of Gniezno tried - and failed - to move the sale of furs, mostly brought by merchants coming from the northeast, to the St. Trinity Fair.

Another model of chronological separation of the two sectors of trade was used in Dolsko and Międzyrzecz. Dolsko, a locality with a long history, lacking expansion options due to its location between lakes and marshes ${ }^{83}$ had only very scarce space available for trade (Fig. 6). Apart from fairs, Sigismund I the Old also established separate markets for trading in horses and small livestock on each Monday between Invocabit Sunday and St. John the Baptist's Day ${ }^{84}$ A similar situation occurred in Międzyrzecz, where, in the fifteenth century, two fairs established by Casimir IV Jagiellon were held respectively on the Monday before the Pentecost and on the Monday before St. Bartholomew's Day, while regular markets took place every Monday. The markets were dedicated to horses and oxen trade, while the fairs to other kinds of goods. ${ }^{85} \mathrm{In}$ 1565, when Międzyrzecz was designated to host interregional cattle trade, oxen fairs were established on St. Trinity's Day and the third day after the Nativity of Mary. ${ }^{86}$

The issue of insufficient space was resolved in a different way in Łowicz. According to documents from the canonical visitation in 1511, horse and cattle markets were held in the outskirts of the town Podgrodzie - in the period between Septuagesima Sunday and St. John the Baptist's Day. ${ }^{87} \mathrm{~A}$ fair was held on the last day of the market period; another one took place on Sunday Conductus Paschae (the first Sunday after Easter). The designated area was situated directly by the river Bzura and surrounding meadows, creating favourable grazing conditions for several months. As it transpired from the canonical visitation, fairs taking place at all three market squares were to be thus differentiated by the type of goods sold: "Item in omnibus tribus civitatibus suprascriptis temporibus fororum annualium talis est distinctio et modus, putta:

${ }^{83}$ M. Słomski, "Dolsk", in: Atlas historyczny Polski, pp. 380-398.

${ }^{84}$ MK 25, ff. 306-307; Matricularum Regni Poloniae summaria, vol. 4, pt. 1, Varsoviae, 1910, issue 1893.

85 Städtebuch des Landes Posen, ed. H. Wuttke, Posen, 1864, issue 102, p. 92.

86 See footnote no. 65.

87 Visitationes bonorum archiepiscopatus necnon capituli Gnesnensis saeculi XVI, ed. B. Ulanowski, Kraków 1920, p. 6. 
curruum mercatorum alias cramow pannicidarum etc., extunc in alia equi et pecora alternatis vicibus venduntur, ita sicut in quolibet circulo duplex forum annuale mercium, ita duplex forum equorum et aliorum quadrupedum." 88

\section{Conclusions}

To sum up, we can ascertain that oxen trade shaped the Polish landscape both on the micro- and the macro-scale. This lucrative branch of trade influenced the use of space both directly - as it required maintaining sites guaranteeing the animals access to feed and water as well as adequate road infrastructure - and indirectly, as the schedule of fairs needed to be adapted to the speed of transporting livestock, which was different than in the case of other goods, and networks of customs houses had to be adjusted to new trade routes. The influence exerted by oxen trade on towns depended on many factors, mainly on the intensity of trade in relation to the town's size, but also on the available infrastructure. Towns strove to keep activities connected to cattle trade within the boundaries of the market square in order to guarantee buyers equal access to merchandise and keep control over the quality of the goods sold. However, in the cases when the amount of traded goods increased rapidly, additional market places were established outside the town walls, the sooner the scantier was the space available within the town boundaries. Another solution which reduced the peaks in trade intensity was to organise specialty fairs for cattle trade separately from fairs focusing on other goods, thus spreading the merchandise flows over time. However, these issues still require to be studied in detail, both focusing on individual centres in cattle trade and carrying out comparative research covering several regions. The issues discussed in the present paper and the proposed research questions certainly do not exhaust the subject, they only indicate future possibilities in analysing source materials.

Translated by Paulina Wacławik

${ }^{88}$ Ibid. See Z. Morawski, "Łowicz średniowieczny”, in: Dzieje miasta Eowicz, ed. R. Kołodziejczyk, Warszawa, 1986, pp. 72-74. 


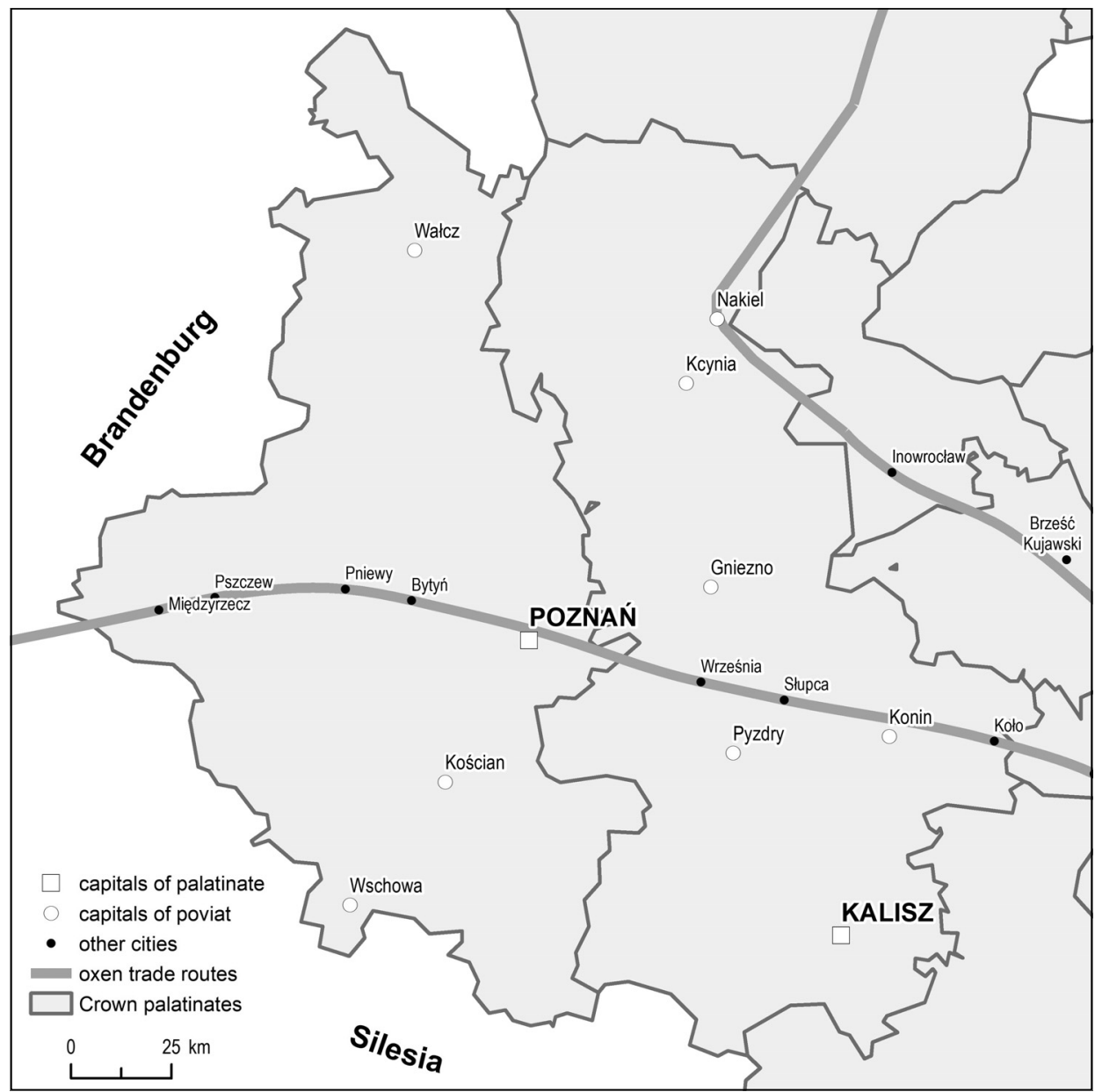

Figure 1. Two main trade routes in Greater Poland in the sixteenth and seventeenth centuries (prep. by A.P. Orłowska, mapped by T. Panecki) 


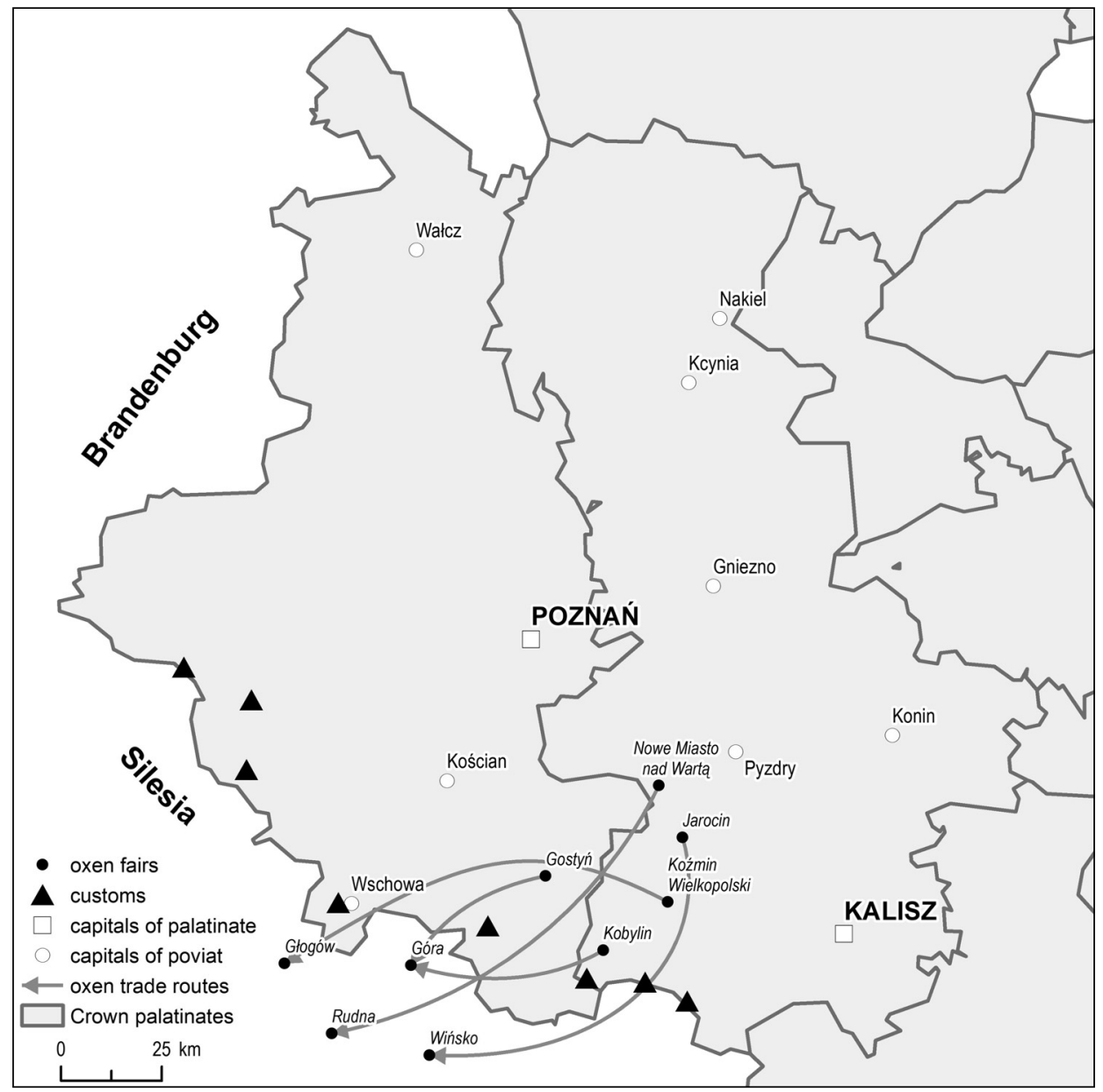

Figure 2. Routes used for driving cattle abroad according to the list of fairs and customs chambers from the sixteenth century (source: Spis zalecen na temat prawidtowego zachowania podczas obserwacji handlu wołami na jarmarkach $i$ komorach celnych Wielkopolski, The Central Archives of Historical Records in Warsaw, Zbiór Dokumentów Papierowych, ref. no. 3780, prep. by A.P. Orłowska, mapped by T. Panecki, in: A.P. Orłowska, B. Nowożycki, G. Pac, "Handel wołami na terenie Wielkopolski i Śląska w świetle szesnastowiecznego spisu jarmarków i komór celnych", Studia Geohistorica, 4, 2016, pp. 158-159) 


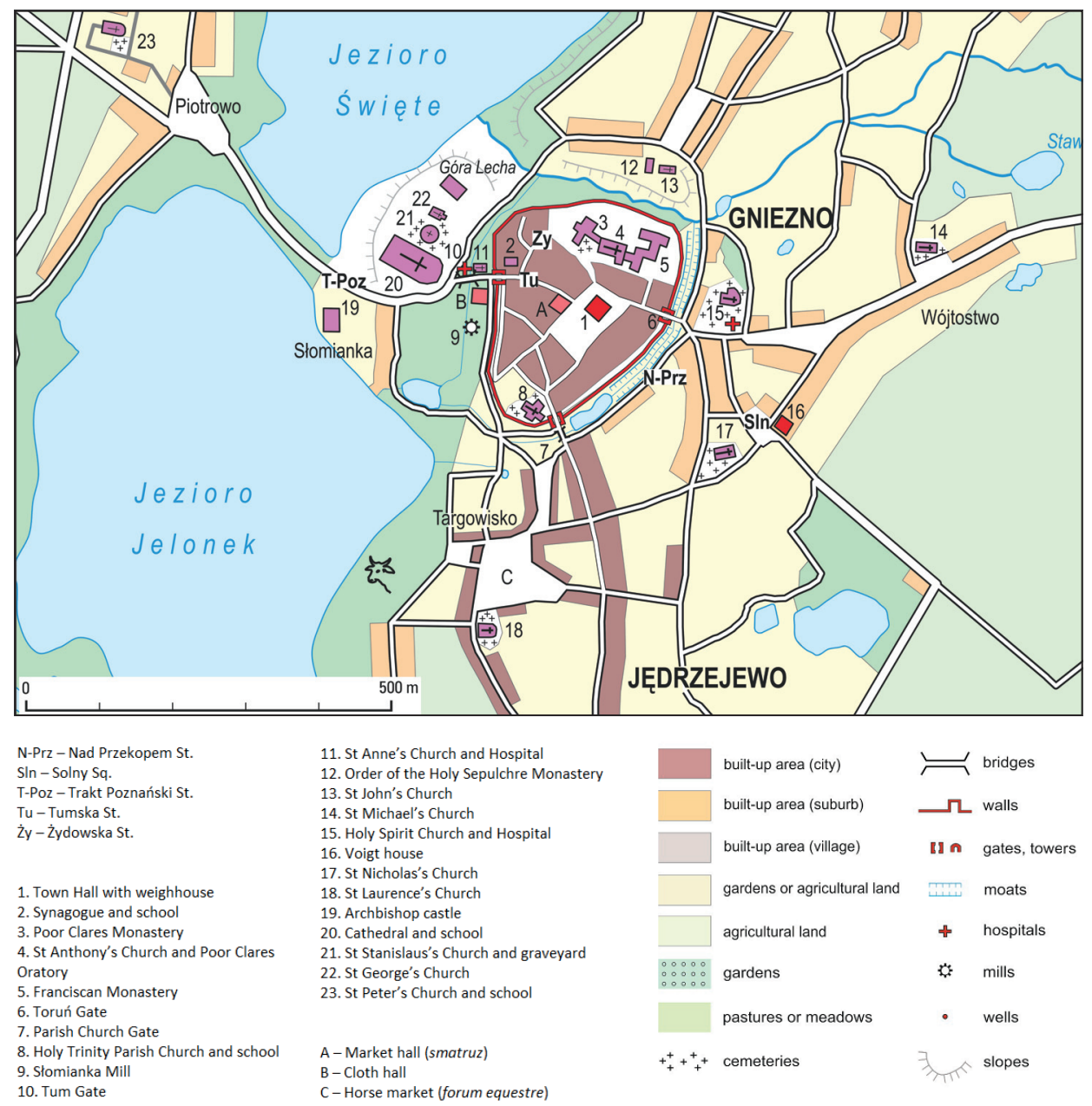

Figure 3. The city plan of Gniezno in the second half of the sixteenth century (source: Gniezno w drugiej połowie XVI wieku, prep. by A.P. Orłowska, mapped by T. Panecki, K. Słomska, in: Wielkopolska $w$ drugiej połowie XVI wieku, part 1: Mapy. Plany, ed. K. Chłapowski, M. Słoń, prep. by A. Borek et al., Warszawa 2017 [Series: Atlas Historyczny Polski. Mapy Szczegółowe XVI wieku], no. 8; modified by T. Panecki and A.P. Orłowska) 


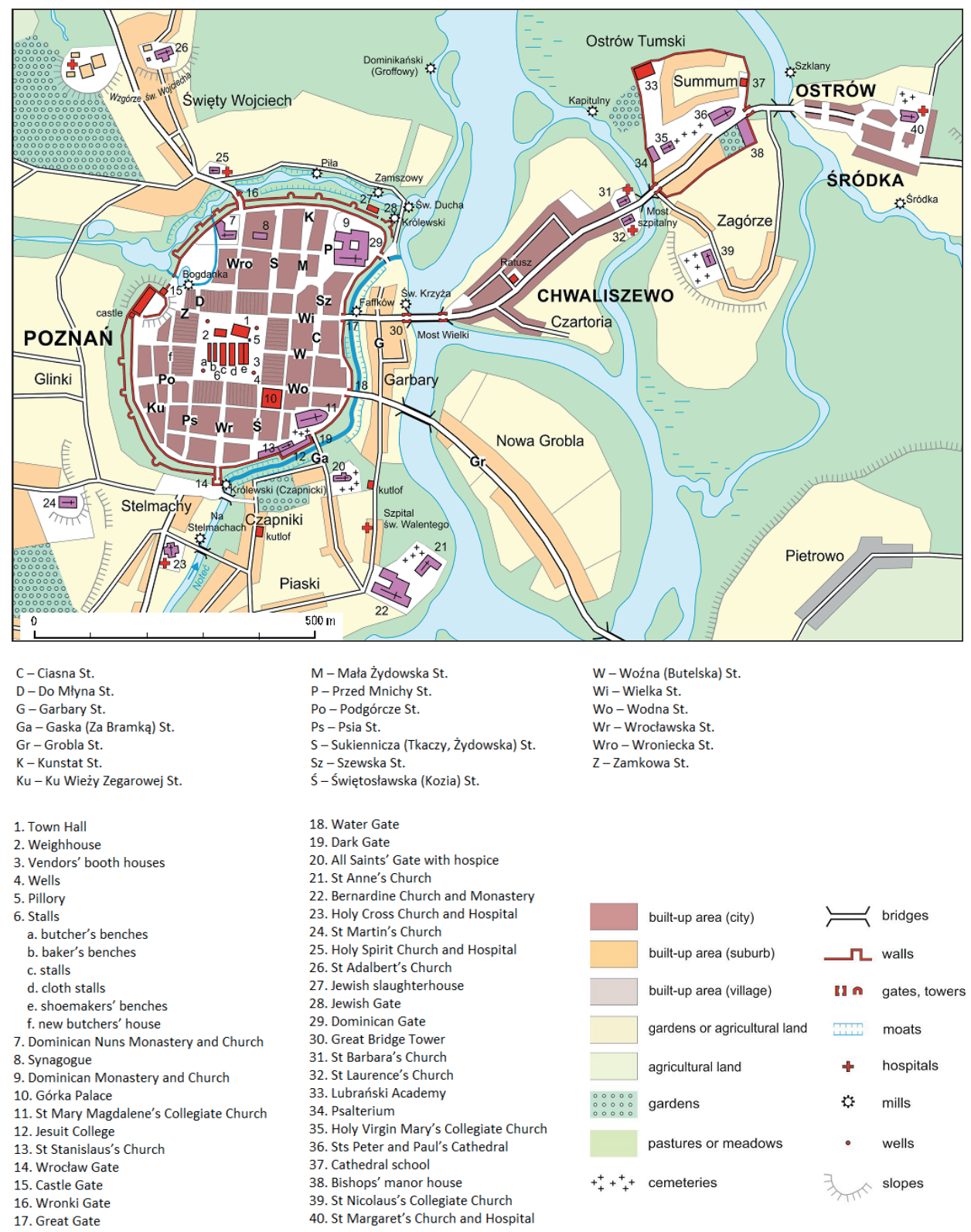

Figure 4. The city plan of Poznan in the second half of the sixteenth century (source: Poznań $w$ drugiej połowie XVI wieku, prep. by E. Rutkowska, P. Dembiński, mapped by E. Rutkowska, K. Słomska, in: Wielkopolska $w$ drugiej połowie XVI wieku, part 1: Mapy. Plany, ed. K. Chłapowski, M. Słoń, prep. by A. Borek et al., Warszawa 2017 [Series: Atlas Historyczny Polski. Mapy Szczegółowe XVI wieku], no. 6; modified by T. Panecki and A.P. Orłowska) 


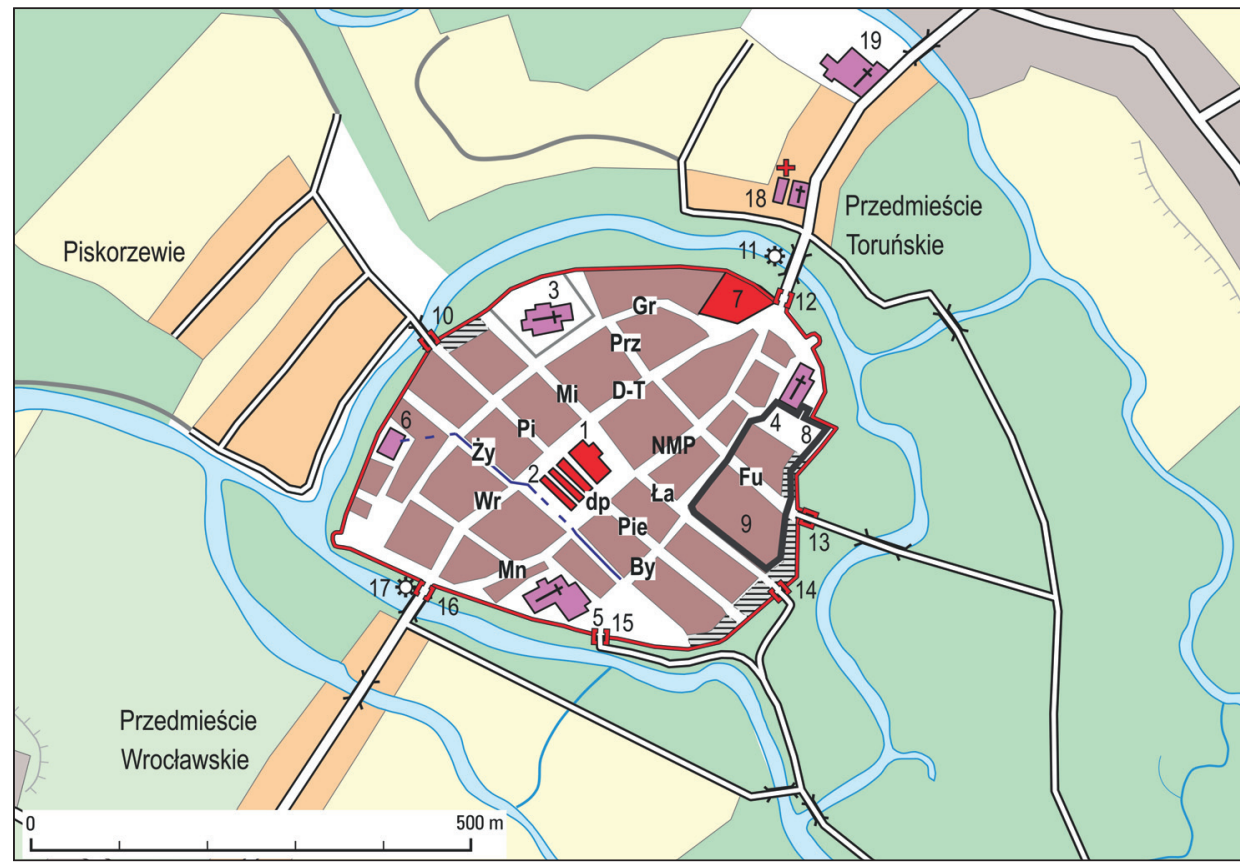

$\begin{array}{ll}\text { By - Bydlęca St. } & \text { 1. Town Hall } \\ \text { D-T - Długa St. or Toruńska St. } & \text { 2. Stalls } \\ \text { Fu - Furteczna/Forteczna St. } & \text { 3. St Nicolaus's Parish Church } \\ \text { KSz - 'Ku szubienicom' Rd. } & \text { 4. Holy Virgin Mary's Collegiate Parish Church } \\ \text { Ła - Łaziebna St. } & \text { 5. Franciscan Monastery and St Stanislaus's Church } \\ \text { Mi - Św. Mikołaja St. } & \text { 6. Synagogue } \\ \text { Mn - Mnichów St. } & \text { 7. Castle } \\ \text { NMP - Najświętszej Marii } & \text { 8. Archbishop palace } \\ \text { Panny St. } & \text { 9. Site of a future Jesuit Monastery } \\ \text { Pie- Piekarska St. } & \text { 10. Piskorzewo Gate } \\ \text { Pi - Piskorzewska St. } & \text { 11. Mill } \\ \text { Prz - Przeczna St. } & \text { 12. Toruń/Tyniec Gate } \\ \text { Wr - Wrocławska St. } & \text { 13. East gate (with no name) } \\ \text { Zm - Zamkowa St. } & \text { 14. taziebna Gate } \\ \text { Ży - Żydowska St. } & \text { 15. 'Nad Kanałem' Gate } \\ & \text { 16. Wroclaw Gate } \\ & \text { 17. Wroclaw Gate Mill } \\ & \text { 18. Holy Spirit Church and Hospital } \\ & \text { 19. Bernardine Church and Monastery }\end{array}$

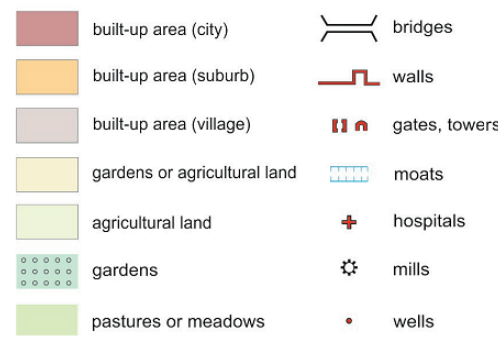

Figure 5. The city plan of Kalisz in the second half of the sixteenth century (source: Kalisz w połowie XVI wieku, prep. by U. Sowina, T. Zwiazek, T. Panecki, mapped by T. Panecki, K. Słomska, in: Wielkopolska $w$ drugiej połowie XVI wieku, part 1: Mapy. Plany, ed. K. Chłapowski, M. Słoń, prep. by A. Borek et al., Warszawa 2017 [Series: Atlas Historyczny Polski. Mapy Szczegółowe XVI wieku], no. 7; modified by T. Panecki and A.P. Orłowska) 


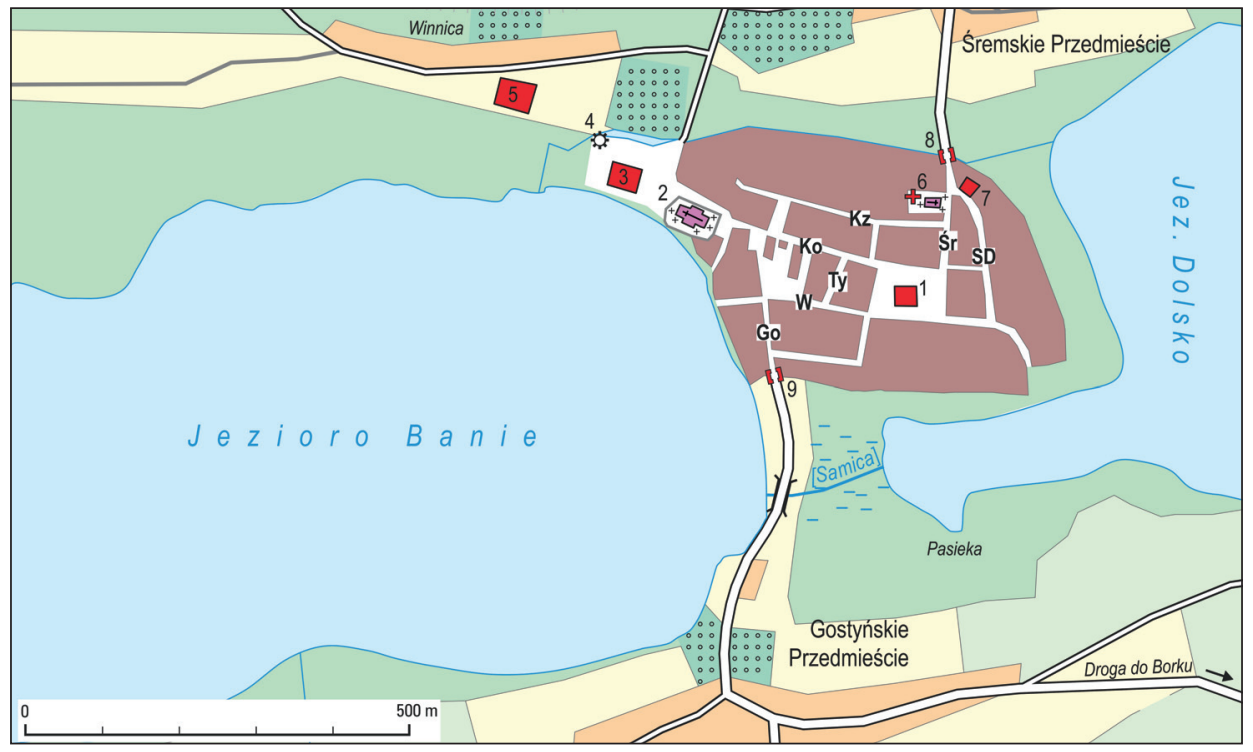

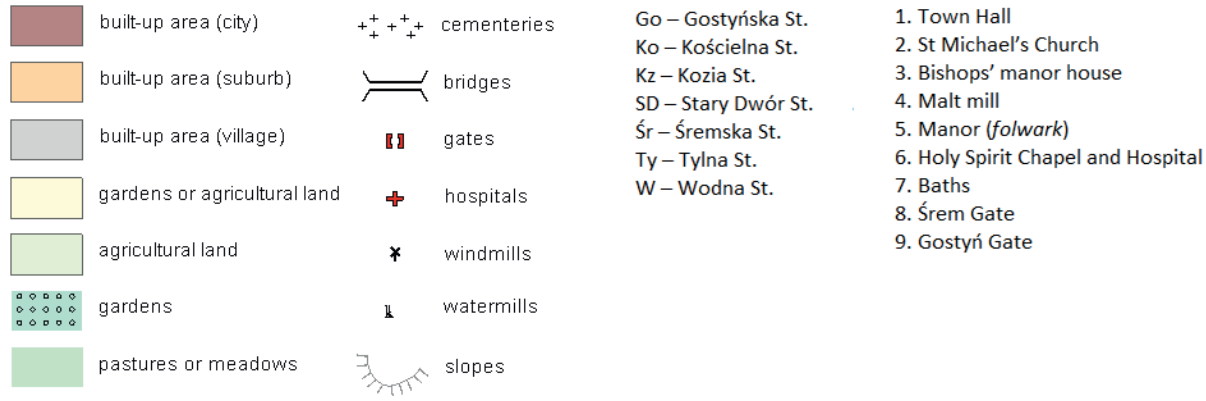

Figure 6. The city plan of Dolsk in the second half of the sixteenth century (source: Dolsk $w$ drugie połowie XVI wieku, oprac. M. Słomski, mapped by T. Panecki, K. Słomska, in: Wielkopolska $w$ drugiej połowie XVI wieku, part 1: Mapy. Plany, ed. K. Chłapowski, M. Słoń, prep. by A. Borek et al., Warszawa 2017 [Series: Atlas Historyczny Polski. Mapy Szczegółowe XVI wieku], no. 11; modified by T. Panecki and A.P. Orłowska) 


\section{Bibliography}

Adler G., "Das großpolnische Fleischergewerk vor 300 Jahren", in: Zeitschrift der Historischen Gesellschaft für die Provinz Posen, 9, 1894, pp. 209-372.

Arłamowski K., "Klucz medycki starostwa przemyskiego w XVI w.", in: Studia z historii społecznej $i$ gospodarczej poświęcone prof. dr. Franciszkowi Bujakowi, Lwów, 1931, pp. 133-161.

Bartoszewicz H., "Drogi handlowe ziemi chełmińskiej”, Miscellanea Historico-Archivistica, 6, 1996, p. 54.

Baszanowski J., Z dziejów handlu polskiego $w$ XVI-XVIII w. Handel wołami, $2^{\text {nd }}$ ed., Szczęsne, 2017.

Bogucka M., "Fairs in Early Modern Poland", in: Jahrmärkte und Stadtentwicklung in Europa = Foires, marchés annuels et développement urbain en Europe, ed. F. Irsigler, M. Pauly, Trier, 2007, pp. 243-251.

Bogucka M., "Peoples of the Fairs. Fairs. Organizers and Participants in the Early Modern Poland", in: Fiere e mercati nella integrazione delle economie europee. Secc. XIII-XVIII. Prato, 8-12 maggio 2000, ed. S. Cavaciocchi, Firenze, 2001, pp. 921-932.

Chodyński A.A., Dawne ustawy Kalisza, Warszawa, 1875.

Corpus iuris polonici. Sect. 1, Privilegia, statuta, constitutiones, edicta, decreta, mandata regnum Poloniae spectantia comprehendis, vol. 3, Annos 1506-1522 continens typis mandavit adnotationibus instruxit Osvaldus Balzer, published by F. Zigel, Petersburg, 1908.

Czacharowski A., "Jahrmärkte und Messen im mittelalterlichen Polen", in: Fiere e mercati nella integrazione delle economie europee. Secc. XIII-XVIII. Prato, 8-12 maggio 2000, ed. S. Cavaciocchi, Firenze, 2001, pp. 235-241.

Czaja R., "Gospodarcze znaczenie jarmarków w państwie zakonu krzyżackiego w Prusach", in: Studia nad dziejami miast i mieszczaństwa w średniowieczu, vol. 2, ed. R. Czaja, J. Tandecki, Toruń, 1996, pp. 121-132.

Czaja R., "Jahrmärkte im Ordensland Preußen im Mittelalter", in: Das Preußenland als Forschungsaufgabe. Eine europäische Region in ihren geschichtlichen Bezügen, ed. B. Jähnig, Lüneburg, 2000, pp. 319-328.

Dembinski P., "Poznański zespół osadniczy", in: Atlas historyczny Polski. Wielkopolska $w$ drugiej połowie XVI wieku, ed. H. Rutkowski, M. Słoń, pt. 2: Komentarz, indeksy, Warszawa, 2017, pp. 292-313.

Drozdowski M., “Życie gospodarcze miasta”, in: Dzieje Poznania, ed. J. Topolski, Warszawa-Poznań, 1988, pp. 455-475.

Dunin-Wasowiczowa A., "Spatial Changes in Poland under the Impact of the Economic of the $16^{\text {th }}$ and $17^{\text {th }}$ Centuries", in: The Early-Modern World-System in Geographical Perspective, ed. H.J. Nitz, Stuttgart, 1993, pp. 172-190.

Dygo M., "Wschód i Zachód: gospodarka Europy w XIV i XV wieku", in: Ziemie polskie wobec Zachodu. Studia nad rozwojem średniowiecznej Europy, ed. R. Czaja, M. Dygo, S. Gawlas, G. Myśliwski, K. Ożóg, Warszawa, 2006, p. 177-194. 
Dzieje miast i mieszczaństwa w Polsce przedrozbiorowej, ed. H. Samsonowicz, M. Bogucka, Wrocław, 1986.

Fornella S., "Rola hodowli, rzeźnictwa i handlu mięsem w życiu gospodarczym Świecia nad Wisła", Studenckie Teki Historyczne, 1, 2002, pp. 9-13.

Grochulska B., "Jarmarki w handlu polskim w drugiej połowie XVIII w.", Przeglad Historyczny, 64, 1973, no. 4, pp. 793-820.

Horn M., "Handel wołami na Rusi Czerwonej w pierwszej połowie XVII wieku", RDSG, 24, 1962, pp. 73-88.

Irsigler F., "Messen, Jahrmärkte und Stadtentwicklung in Europa: Mittelalter und frühe Neuzeit", in: Jahrmärkte und Stadtentwicklung in Europa = Foires, marchés annuels et développement urbain en Europe, ed. F. Irsigler, M. Pauly, Trier, 2007, pp. 1-24.

Jenks S., "The Missing Link: Distribution Revolution the $15^{\text {th }}$ Century", in: Textiles and Medieval Economy: Production, Trade and Consumption of Textiles $8^{\text {th }}$ to $16^{\text {th }}$ Centuries, ed. A.L. Huang, C. Jahnke, Oxford, 2015, pp. 230-252.

Karwasińska J., "Archiwa Skarbowe dawnej Rzeczpospolitej”, in: Straty archiwów i bibliotek warszawskich $w$ zakresie rękopiśmiennych źródet historycznych, vol. 1, Warszawa, 1957, pp. 70-125.

Kiryk F., Urbanizacja Matopolski: województwo sandomierskie, Kielce, 1994.

Koczy L., Handel Poznania do połowy XVI w., $1^{\text {st }}$ ed., Poznań, 1930.

Ksieggi celne Korony $z$ drugiej połowy XVI wieku, ed. S. Kazusek, Kielce, 2017, pp. 195-203.

Kurkowski J., "Sieć jarmarczna województwa lubelskiego w XVI wieku", Kwartalnik Historii Kultury Materialnej, 34, 1986, no. 2, pp. 37-59.

Kuś J., "Jarmarki jarosławskie i ich wpływ na rozwój miasta w XVI i XVII wieku", Rocznik Historyczno-Archiwalny, 9, 1995, pp. 29-43.

Leitgerber J., $Z$ dziejów handlu i kupiectwa poznańskiego za dawnej Rzeczypospolitej Polskiej, Poznań, 1929.

Małowist M., Studia z dziejów rzemiosta w okresie kryzysu feudalizmu w Zachodniej Europie w XIV i XV wieku, Warszawa, 1954.

Małowist M., Wschód a Zachód Europy w XIII-XVI w.: konfrontacja struktur społeczno-gospodarczych, Warszawa, 1973.

Mączak A., "Rinderhandel und Rinderhaltung im nordwesteuropäischen Künstengebiet vom 15. bis zum 19. Jahrhunder', Heinz Wiese, Johan Bölts, Stuttgart 1966: [recenzja]", Przeglad Historyczny, 60, 1969, no. 4, pp. 731-735.

Modrzyński P.M., "Prawne aspekty hodowli zwierząt w średniowiecznych miastach ziemi chełmińskiej i terenów przygranicznych", Rocznik Toruński, 42, 2015, pp. 203-220.

Morawski Z., "Łowicz średniowieczny”, in: Dzieje miasta Łowicz, ed. R. Kołodziejczyk, Warszawa, 1986, pp. 51-74.

Myśliwski G., "Strefa sudecko-karpacka i Lwów. Miejsce Śląska, Małopolski i Rusi Czerwonej w gospodarce Europy Zachodniej (połowa XIII-poczatek XVI wieku)", in: Ziemie polskie wobec Zachodu. Studia nad rozwojem 
średniowiecznej Europy, ed. R. Czaja, M. Dygo, S. Gawlas, G. Myśliwski, K. Ożóg, Warszawa, 2006, pp. 247-312.

Najstarsze rachunki przemyskie, ed. A. Łosowska, M. Schmidt, Przemyśl, 2019. Orłowska A.P., Nowożycki B., Pac G., "Handel wołami na terenie Wielkopolski i Ślaska w świetle szesnastowiecznego spisu jarmarków i komór celnych", Studia Geohistorica, 4, 2016, pp. 158-161.

Paluchowski P., "Miejsca i terminy jarmarków na terenie Prus Królewskich i Książęcych w końcu XVI wieku na podstawie wykazów z gdańskich kalendarzy", Czasy Nowożytne, 24, 2011, pp. 37-59.

Przywileje miasta Poznania, ed. W. Maisel, Poznań, 1994.

Rybarski R., Handel i polityka handlowa Polski $w$ XVI stuleciu, $1^{\text {st }}$ ed., Poznań, 1928-1930; $2^{\text {nd }}$ ed., Warszawa, 1958.

Samsonowicz H., "Les foires en Pologne au XVe et XVI" siècles sur la toile de fond de la situation en Europe", in: Der Außenhandel Ostmitteleuropas 1450-1650, ed. I. Bog, Wien, 1971, pp. 246-259.

Samsonowicz H., "Jarmarki w Polsce na tle sytuacji gospodarczej w Europie w XV-XVI w.”, in: Europa - Słowiańszczyzna - Polska, ed. J. Bardach, Poznań, 1970, pp. 523-532.

Samsonowicz H., "Niektóre cechy charakterystyczne sieci jarmarcznej w Polsce późnego średniowiecza”, in: Studia nad dziejami miast $i$ mieszczaństwa $w$ Średniowieczu, vol. 1, ed. M. Bogucka, A. Czacharowski, Torun, 1994, pp. 37-59.

Samsonowicz H., "Polska w gospodarce europejskiej późnego średniowiecza", in: Pamiętnik Powszechnego Zjazdu Historyków Polskich w Lublinie, vol. 1, Warszawa, 1968, pp. 92-102.

Samsonowicz H., "Przemiany osi drożnych w Polsce późnego średniowiecza", Przeglad Historyczny, 64, 1973, no. 4, pp. 967-716.

Samsonowicz H., Mączak A., "Feudalism and Capitalism. A Balance of Changes in East-Central Europe", in: East-Central Europe in Transition from Fourteenth to the Seventeenth Century, ed. A. Maczak, H. Samsonowicz, P. Burke, Cambridge, 1985, pp. 6-23.

Skierska I., Sabbatha sanctifices. Dzień święty w średniowiecznej Polsce, Warszawa, 2008.

Słomski M., "Dolsk", in: Atlas historyczny Polski. Wielkopolska w drugiej połowie XVI wieku, ed. H. Rutkowski, M. Słoń, pt. 2: Komentarz, indeksy, Warszawa, 2017, pp. 380-398.

Słoń M., "Miasta prywatne w sieci miejskiej Wielkopolski XV-XVI wieku", RDSG, 77, 2016, pp. 93-123.

Sowina U., Związek T., Panecki T., "Kalisz w połowie XVI wieku”, in: Atlas historyczny Polski. Wielkopolska w drugiej połowie XVI wieku, ed. H. Rutkowski, M. Słoń, pt. 2: Komentarz, indeksy, Warszawa, 2017, pp. 313-332.

Topolski J., "Przyczyny powstania i rozwój folwarku pańszczyźnianego", in: Dzieje Wielkopolski do roku 1793, ed. J. Topolski, vol. 1, Warszawa, 1963, pp. 445-458. 
Topolski J., "Rola Gniezna w handlu europejskim od XV do XVII wieku", Studia z dziejów Wielkopolski i Pomorza, 7, 1962, pp. 5-78.

Visitationes bonorum archiepiscopatus necnon capituli Gnesnensis saeculi XV, ed. B. Ulanowski, Kraków, 1920.

Westermann E., "Die Bedeutung des Thüringer Saigerhandels für den mitteleuropäischen Handel an der Wende vom 15. zum 16. Jahrhundert”, Jahrbuch für die Geschichte Mittel- und Ostdeutschlands, 21, 1972, pp. 67-92.

Weymann S., "Ze studiów nad zagadnieniem dróg w Wielkopolsce od X do XVIII wieku", Przeglad Zachodni, 9, 1953, no. 2, pp. 194-253.

Wolański M., Zwiqzki handlowe Ślaska $z$ Rzeczapospolita $w$ XVII wieku, Wrocław, 1961.

Wyrobisz A., "Uwagi o kalendarzu jarmarków w miastach Korony w XVI wieku", in: Studia nad dziejami miast i mieszczaństwa $w$ Średniowieczu, vol. 1, ed. M. Bogucka, A. Czacharowski, Torun, 1994, pp. 27-32.

Wyrozumski J, "Hodowla w średniowiecznym Krakowie," in: Czas, przestrzeń, praca w dawnych miastach: studia ofiarowane Henrykowi Samsonowiczowi w sześćdziesiata rocznice urodzin, ed. A. Wyrobisz, M. Tymowski, Warszawa, 1991, pp. 431-435.

Zajęcki M., "Przepisy dotyczące chowu zwierząt w większych miastach Polski przedrozbiorowej”, Studia z Dziejów Państwa i Prawa Polskiego, 10, 2007, pp. 105-125.

Zaremska H., "Z dziejów handlu polsko-litewskiego: lokacje w Koronie i na Mazowszu w latach 1386-1501”, Przeglad Historyczny, 64, 1973, no. 4, pp. 717-728.

Związek T., "Drogi", in: Atlas historyczny Polski. Wielkopolska w drugiej połowie XVI wieku, ed. H. Rutkowski, M. Słoń, pt. 2: Komentarz, indeksy, Warszawa, 2017, pp. 268-291.

Anna Paulina Orłowska

Patrycja Szwedo-Kiełczewska

Oxen trade from the fifteenth to the beginning of the seventeenth century and its relations with the environment and space - case study

Greater Poland

(Summary)

The article discusses how oxen trade shaped Polish landscape both on the micro- and the macro-scale. This lucrative branch of trade influenced the use of space both directly - as it required maintaining sites guaranteeing the animals access to feed and water as well as adequate road infrastructure - and indirectly, as the schedule of fairs needed to be adapted to the speed of transporting livestock, which was different than in the case of other goods, and networks of customs houses had to be adjusted to new trade routes. The influence exerted by oxen trade on towns depended on many factors, mainly on 
the intensity of trade in relation to the town's size, but also on the available infrastructure. Towns strove to keep activities connected to cattle trade within the boundaries of the market square in order to guarantee buyers equal access to merchandise and keep control over the quality of the goods sold. However, in the cases when the amount of traded goods increased rapidly, additional market places were established outside the town walls, the sooner the scantier was the space available within the town boundaries. Another solution which reduced the peaks in trade intensity was to organise specialty fairs for cattle trade separately from fairs focusing on other goods, thus spreading merchandise flows over time. However, these issues still require to be studied in detail, both focusing on individual centres of cattle trade and carrying out comparative research covering several regions. The issues discussed in the present paper and the proposed research questions certainly do not exhaust the subject, they only indicate future possibilities in analysing source materials.

Anna Paulina Orłowska - absolwentka historii na Uniwersytecie Warszawskim oraz historii sztuki na Uniwersytecie Christiana-Albrechta w Kilonii (Niemcy), gdzie przygotowała rozprawę pod kierunkiem Gerharda Fouqueta i Rolfa Hammela-Kiesowa poświęconą kupcowi gdańskiemu Johanowi Pyremu. Jako post-doc prowadziła projekt MSCA „Annual Fairs in Greater Poland from the Late Middle Ages to the Deluge (1385-1655)" i obecnie jest wykonawca w projektach Zakładu Atlasu Historycznego Instytutu Historii im. Tadeusza Manteuffla Polskiej Akademii Nauk.

Anna Paulina Orłowska - graduate in history from the University of Warsaw and art history from the Christian-Albrecht University of Kiel (Germany), where she wrote her doctoral thesis on Johan Pyre, a merchant from Gdańsk, under Gerhard Fouquet and Rolf Hammel-Kiesow. As a postdoctoral researcher she worked on a MSCA project titled "Annual Fairs in Greater Poland from the Late Middle Ages to the Deluge (1385-1655)". She currently works on projects of the Department of the Historical Atlas in the Tadeusz Manteuffel Institute of History, Polish Academy of Sciences.

E-mail: anna.p.orlowska@gmail.com

Patrycja Szwedo-Kiełczewska - doktorantka na Wydziale Nauk o Kulturze i Sztuce Uniwersytetu Warszawskiego. Prowadzi badania nad komunikacją społeczną w późnym średniowieczu, ze szczególnym uwzględnieniem problematyki miejskiej. W latach 2017-2019 zatrudniona jako asystent w Zakładzie Atlasu Historycznego Instytutu Historii im. Tadeusza Manteuffla Polskiej Akademii Nauk, przy realizacji projektu „Annual Fairs in Greater Poland from the Late Middle Ages to the Deluge (1385-1655)". 
Patrycja Szwedo-Kiełczewska - doctoral student at the Faculty of Culture and Arts of the University of Warsaw. She researches social communication in the Late Middle Ages with particular emphasis on urban issues. In the years 2017-2019, she worked as an assistant at the Department of the Historical Atlas in the Tadeusz Manteuffel Institute of History, Polish Academy of Sciences, dealing with the project "Annual Fairs in Greater Poland from the Late Middle Ages to the Deluge (1385-1655)".

E-mail: patrycja.szwedo@uw.edu.pl 